\title{
W trosce o rodzinę... Rozważania nad praktycznym wymiarem niesienia interdyscyplinarnej pomocy dziecku i rodzinie $w$ świetle systemu pieczy zastępczej
}

Caring about the family... Some considerations regarding the practical aspect of providing interdisciplinary aid for a child and for the family in the light of selected threats

Abstract: A modern family, facing the changes taking place in today's world as well as different conditions among which are e.g. a number of abnormal phenomena and negative influences, is constantly exposed to numerous challenges. The difficulties that arise during the daily performance of basic activities or during the execution of certain tasks may pose a threat to the durability of the family community. This is the reason for the care about the family's condition and about the form it may take. A family - broadly speaking is a place where a human being is born, raised, where he or she collects experience and learns about the surrounding world. It also constitutes a place for the growth of younger generations and for sharing certain values. John Paul II was pointing out to the fact that a family is also a basic institution of social life and that it participates in society's development. Seeing the importance of the role played by the family in the life of an individual and of the entire society, the experts highlight that now, a necessary thing is to pay due attention to providing adequate aid that would correspond - basing on a proper analysis of the family's situation - to its real needs. The actions aiming at providing support to the family should concentrate largely on its resources, its potential and its strengths. The considerations raised in this paper - in selected aspects - are 
aimed to indicate the proper approach to family support. What seems important is the practical aspect of creating a plan for helping a child and its family in the context of The Act of 9 June 2011 on Family Support and on the System of Foster Care. The analysis also encompasses interdisci- plinary aid provided by specialists in different areas and by other people accompanying the family in the improvement of its living conditions.

Keywords: family, child, parenthood, foster care system, interdisciplinary aid

Obecna rzeczywistość sytuuje rodzinę w szerokim kontekście zachodzących przemian i rozmaitych uwarunkowań, „tkwiących wewnątrz i na zewnątrz instytucji rodziny"'. Należy zwrócić uwagę na różnego rodzaju zagrożenia, które stanowią jednocześnie przejawy - poruszanej w dyskursie wielu badaczy kondycji współczesnej rodziny. Literatura przedmiotu wskazuje m.in. na nietrwałość zawieranych małżeństw oraz na niejednokrotnie wiążące się z nią samotne rodzicielstwo. Podejmowane są także rozważania dotyczące problemu bezrobocia w Polsce, w tym wśród młodych, wykształconych osób czy funkcjonowania rodzin migracyjnych i zjawiska tzw. eurosieroctwa. Omawia się przy tym kwestie uzależnień od substancji psychoaktywnych, gier komputerowych czy internetu (problemu szczególnie zauważalnego wśród dzieci i młodzieży) ${ }^{2}$. Wskazuje się również, iż dzisiejsze rodziny mogą odczuwać pewien „niedosyt uczuciowy, rozluźnienie więzi i relacji pomiędzy poszczególnymi członkami rodziny, mające negatywny wpływ na ich życie wewnętrzne"3. Często prowadzi to do powstawania i nasilania się konfliktów rodzinnych, zaniedbań lub niewydolności w sferze opiekuńczo-wychowawczej ${ }^{4}$.

\section{Rodzina w kontekście swoich funkcji i zasobów}

Rodzina powinna być niewątpliwie miejscem sprzyjającym rozwojowi wszystkich jej członków, gdyż „stanowiła i nadal stanowi pierwsze, najważniejsze

1 A. Kotlarska-Michalska, Dysfunkcje rodziny jako efekt przemian makrostrukturalnych, [w:] Pomoc społeczna wobec rodzin. Interdyscyplinarne rozważania o publicznej trosce o dziecko i rodzinę, red. D. Trawkowska, Toruń 2011, s. 17.

2 Por. M. Winiarski, Opieka, pomoc i wsparcie jako wymiary pracy socjalnej z dziećmi, młodzieżą i rodzina, [w:] Praca socjalna z dziećmi, młodzieżą i rodzina, red. M. Ruszkowska, M. Winiarski, Warszawa 2014, s. 44-47.

3 M. Ruszkowska, Diagnoza rodzin zastępczych w obliczu dylematów współczesności, Warszawa 2013, s. 7.

4 Por. tamże. 
środowisko wychowawcze i miejsce, gdzie kształtuje się osobowość młodego pokolenia" . Jednakże w obliczu niestabilności w różnych obszarach życia, trudności w wypełnianiu przez rodzinę swoich funkcji i realizacji wynikających z nich zadań konieczne wydaje się objęcie refleksją problematyki niesienia pomocy dziecku i rodzinie w sytuacjach trudnych, kryzysowych. Można spotkać się z rozmaitymi terminami określającymi rodziny zmagające się z życiowymi problemami - szczególnie obejmującymi sferę opiekuńczo-wychowawczą. Najczęściej nazywa się je „rodzinami niewydolnymi, dysfunkcjonalnymi ${ }^{6}$, zdezorganizowanymi, zdezintegrowanymi, zaniedbanymi, patologicznymi czy też po prostu problemowymi"7.

Literatura przedmiotu wskazuje na wiele - czasem nieznacznie różniących się od siebie - klasyfikacji funkcji rodziny oraz poszczególnych zadań. Można przyjąć, że rodzina powinna realizować następujące funkcje: prokreacyjną (zapewnienie ciągłości pokoleniowej), opiekuńczą (opieka, okazywanie troski, udzielanie pomocy), socjalizacyjną (przyjmowanie i podejmowanie ról społecznych), emocjonalną (rozwój psychiczny, zaspokajanie potrzeb emocjonalnych), edukacyjną (wychowanie, wspomaganie rozwoju w środowisku rodzinnym i instytucjonalnym), ekonomiczną (zdobywanie środków materialnych służących zapewnieniu bytu rodzinie), seksualną (zaspokojenie potrzeb seksualnych małżonków), spójności (gotowość do współpracy, przekazywania tradycji, uczestniczenia w rodzinnych inicjatywach). Przy omawianiu funkcji rodziny wymienia się również jej tzw. psychospołeczne uwarunkowania, do których należą czynniki wewnątrzrodzinne (dojrzałość osobowa, style oddziaływań wychowawczych) oraz determinanty pozarodzinne (przeobrażenia w sferze społeczno-politycznej, rozwój środków masowego przekazu) ${ }^{8}$.

Autorzy podkreślają, że rodzina borykająca się z wybranymi problemami nie powinna być postrzegana wyłącznie w kategoriach określonych dysfunkcji. Warto w tym miejscu zaznaczyć, że rodzina doświadczająca trudnej sytuacji życiowej „wymaga wsparcia nie tylko materialnego, informacyjnego, instru-

5 J. Meissner-Łozińska, Instytucje i organizacje wspierające dziecko i rodzine, [w:] Pomoc, opieka, wsparcie dziecka i rodziny, red. U. Gruca-Miąsik, Rzeszów 2006, s. 78.

6 Dysfunkcjonalność rodziny jest tu rozumiana jako „cecha (lub zespół cech) właściwa rodzinie, która nie potrafi, nie może lub nie chce sprostać zadaniom, które winna realizować jako instytucja. To rodzina, która reprezentuje niewłaściwe postawy wobec zadań, które powinna podjąć. To rodzina, która albo nie podejmuje określonych (oczekiwanych przez społeczeństwo) działań, albo realizuje je niewłaściwie (niezgodnie ze zwyczajowo przyjętymi normami)". A. Kotlarska-Michalska, Dysfunkcje rodziny..., dz. cyt., s. 18.

7 Tamże, s. 16.

8 Por. K. Walęcka-Matyja, Role i funkcje rodziny, [w:] Psychologia rodziny, red. I. Janicka, H. Liberska, Warszawa 2014, s. 107-110. 
mentalnego, ale również wartościującego, duchowego, pedagogicznego"9 $\mathrm{Na}$ rodzinę powinno się spoglądać jak na środowisko zasobów osobistych i zasobów całego systemu rodzinnego. Potencjał ten obecny jest na różnych płaszczyznach przestrzeni życia i funkcjonowania rodziny. Wśród przykładowych zasobów osobistych, którymi dysponują poszczególni jej członkowie, mieszczą się cechy osobowości, poczucie własnej wartości, wiedza i konkretne umiejętności. Zasobami systemu rodzinnego może być np. integralność rodziny, spójność świata wartości, okazywany sobie szacunek i wsparcie. Oprócz integracji rodzinnej wymienia się także obszar wspólnych planów i formułowanych celów, istnienie silnych więzi, charakterystyczną wewnątrzrodzinną komunikację, gotowość do zmiany, ale i posiadane dobra materialne ${ }^{10}$. Jan Paweł II podkreślał istotną rolę społeczeństwa w służbie rodzinie, zwracając uwagę, iż „nie można i nie powinno się pozbawiać rodziny takich zadań, które równie dobrze może ona wypełnić sama [...]; powinno się natomiast popierać w sposób pozytywny i jak najbardziej pobudzać odpowiedzialną jej inicjatywę"11.

Warto więc zaznaczać fakt, że rodzina ${ }^{12}$ jest tym miejscem, w którym człowiek w pierwszej kolejności nabywa pewnych umiejętności i stara się czerpać z rodzinnego kapitału. Natomiast dopiero w drugiej kolejności w procesie socjalizacji następuje korzystanie z zasobów znajdujących się na zewnątrz rodzi$n y^{13}$. Do tego świata zasobów osobistych i zasobów rodziny, rozumianej jako pewna całość, dołącza się jeszcze jedno źródło potencjału, jakim są zasoby społeczności - środowiska, w którym rodzina żyje (chodzi tu o środowisko lokalne, konkretne osoby i instytucje). Trzeba zauważyć, iż dostrzeżenie i właściwe wykorzystanie wybranych pozytywnych aspektów wyróżnionych zasobów pozwala na poszukiwanie oraz przyjmowanie adekwatnych rozwiązań w pracy $\mathrm{z}$ dzieckiem i rodziną ${ }^{14}$.

$9 \quad$ J. Izdebska, Rodzina wspótczesna, jej sytuacja życiowa potrzeba wsparcia, [w:] W trosce o współczesna rodzinę. Teoria, badania, wsparcie. Ujęcie interdyscyplinarne, red. J. Izdebska, A. Popławska, Białystok 2013, s. 179, 342.

10 Por. I. Krasiejko, Metodyka działania asystenta rodziny. Różne modele pracy socjalnej i terapeutycznej z rodzina, Katowice 20122, s. 16-18.

11 Jan Paweł II, Adhort. apost. „Familiaris consortio” (22.11.1981), nr 45.

12 A. Kalus w swoich rozważaniach dotyczących rodziny zastępczej podkreśla na wstępie, iż „rodzina uważana jest przez psychologów rozwojowych za prymarny kontekst rozwoju jednostki”. A. Kalus, Rodzina zastępcza, [w:] Psychologia rodziny..., dz. cyt., s. 354.

13 Por. Z. Kawczyńska-Butrym, Rodziny zależne od pomocy - wsparcie z zewnątrzwykorzystanie zasady domina i synergii (DiS) oraz zasobów rodziny, [w:] Pomoc społeczna wobec..., dz. cyt., s. 77.

14 Por. I. Krasiejko, Metodyka działania..., s. 16-18. 


\section{Konieczność usprawnienia pomocy niesionej dziecku i rodzinie na przykładzie systemu pieczy zastępczej}

Dla zilustrowania problematyki niesienia interdyscyplinarnej pomocy dziecku i rodzinie oraz ze względu na chęć podkreślenia roli współpracy pomiędzy instytucjami wspierającymi rodziny można naświetlić przykład wybranej problematyki pieczy zastępczej. Gdy biologiczna rodzina dziecka nie jest w stanie wypełniać swoich funkcji opiekuńczo-wychowawczych i zapewnić tym samym dziecku odpowiednich warunków do prawidłowego rozwoju, często szuka się pieczy zastępczej wśród członków rodziny, bliskich osób z otoczenia dziecka ${ }^{15}$. Wydaje się, iż najbliżsi członkowie rodziny stworzą najlepsze z możliwych warunki, w których dziecko mogłoby przebywać przynajmniej do czasu uregulowania danej sytuacji rodziny biologicznej. Niestety, rzeczywistość rodzinnej pieczy zastępczej nie zawsze wygląda tak, jak w pierwotnych założeniach. Można by się przyjrzeć w tym miejscu uwarunkowaniom tkwiącym wewnątrz rodziny, jednak ze względu na potrzeby niniejszych rozważań akcent położony zostanie na pewne oddziaływania zewnętrzne.

Przede wszystkim trzeba odnieść się do poziomu organizowanych szkoleń dla kandydatów chcących pełnić rolę rodziny zastępczej dla dziecka. Niejednokrotnie owe szkolenia są przeprowadzane przez osoby, które nie posiadają wystarczającej wiedzy z zakresu specyfiki rodzicielstwa zastępczego lub też nie mają odpowiedniego doświadczenia w pracy $\mathrm{z}$ takimi rodzinami. Mimo iż żadne szkolenie nie może zaoferować wszystkich odpowiedzi na stawiane pytania związane ze sferą opiekuńczo-wychowawczą, to wydaje się jednak, że powinno się znacznie intensywniej pracować nad podniesieniem poziomu prowadzonych zajęć. Budowałoby to u kandydatów zaufanie do instytucji szkolącej, jak i do nabywanych podczas szkolenia kompetencji rodzicielskich ${ }^{16}$.

Innym przykładem może być problem rozdzielania rodzeństwa przy kierowaniu do pieczy zastępczej, gdzie dzieci przebywają (w najkorzystniejszym wariancie) u dwóch bliskich sobie rodzin. Wówczas pojawiają się często trudności w ustale-

15 Wyniki badań prowadzonych przez Główny Urząd Statystyczny wskazują, iż w 2013 roku „większość dzieci pozbawionych opieki rodziny naturalnej objęta była rodzinną pieczą zastępczą”, z czego większość stanowią rodziny spokrewnione. Opieka nad dzieckiem pozbawionym opieki rodzicielskiej, http://stat.gov.pl/obszary-tematyczne/ warunki-zycia/ubostwo-opieka-spoleczna/opieka-nad-dzieckiem-pozbawionym-opiekirodzicielskiej,5,2.html (12.06.2015).

16 Por. M. Andrzejewski, Rozważania o tożsamości zastępczego rodzicielstwa ( $i$ kilku drobniejszych sprawach), [w:] Pomoc społeczna wobec..., dz. cyt., s. 187-188. 
niu oraz zrealizowaniu harmonogramu wspólnych spotkań dzieci. Wiążą się z tym konflikty między zwaśnionymi rodzinami, nierozwiązane wewnątrzrodzinne problemy czy brak odpowiedniej współpracy z przedstawicielami instytucji pomocowych, którzy nie zawsze są w stanie zaoferować np. właściwe wsparcie wykwalifikowanych mediatorów. Warto mieć przy tym na względzie zdanie specjalistów, którzy zaznaczają, iż wspólne spędzanie wolnego czasu przez dzieci będące rodzeństwem jest niezwykle istotne już dla samej efektywności procesu reintegracji rodziny ${ }^{17}$.

Mając na uwadze dobro dziecka - umieszczonego w pieczy zastępczej przy założeniu jego powrotu do rodziny biologicznej, czyli do jego naturalnego środowiska rozwoju - konieczne wydaje się podejmowanie takich działań, które będą adekwatne do realnych potrzeb zgłaszanych przez rodzinę. Dopiero właściwe rozpoznanie rzeczywistych potrzeb oraz odpowiednia reakcja instytucji pomocowych stanowi podstawę tworzenia skutecznego planu pomocy dziecku i rodzinie. We wstępie Ustawy o wspieraniu rodziny i systemie pieczy zastępczej stwierdza się, że „skuteczna pomoc dla rodziny przeżywającej trudności w opiekowaniu się i wychowywaniu dzieci oraz skuteczna ochrona dzieci i pomoc dla nich może być osiągnięta przez współpracę wszystkich osób, instytucji i organizacji pracujących z dziećmi i rodzicami”"18. Dlatego tak niezwykle istotna jest współpraca o ile jest ona rzeczywiście możliwa - między rodziną zastępczą i biologiczną dziecka oraz współpraca między tymi rodzinami a instytucjami pomocy społecznej ${ }^{19}$.

\section{Instytucje pomocowe $w$ trosce o rodzinę}

Wybrani pracownicy reprezentujący powiatowe centra pomocy rodzinie (koordynator rodzinnej pieczy zastępczej), miejskie ośrodki pomocy społecz-

17 Por. tamże, s. 191.

18 Ustawa z dnia 9 czerwca 2011 roku o wspieraniu rodziny i systemie pieczy zastępczej (Dz. U. z dnia 21 lipca 2011 r. Nr 149, poz. 887).

19 „Do instytucji działających na terenie gmin, powiatów i województw w zakresie pomocy i wsparcia rodzin należą: miejskie i gminne ośrodki pomocy społecznej, powiatowe centra pomocy rodzinie, miejskie ośrodki pomocy rodzinie, ośrodki wsparcia, w tym dzienny dom pomocy, środowiskowy dom samopomocy, klub samopomocy, noclegownie, jadłodajnie, ośrodki interwencji kryzysowej, uniwersytet trzeciego wieku, warsztaty terapii zajęciowej, podmioty ekonomii społecznej, policja, organizacje pozarządowe, placówki szkolne, wychowawcze, opiekuńcze, poradnie psychologiczno-pedagogiczne, placówki wsparcia dziennego, sąd rodzinny, ośrodki kultury, gminna komisja rozwiązywania problemów alkoholowych, kościoły, związki wyznaniowe, placówki ochrony zdrowia, ośrodek adopcyjny, urzędy pracy, służba więzienna, wolontariusze”. M. Makarinska i in., Współpraca instytucji pomocy społecznej z innymi instytucjami na terenie gminy, powiatu, województwa zajmującymi się pomoca i wsparciem rodzin i jej wpływ na skuteczność działań pomocy społecznej, red. M. Zajdel-Ostrowska i in., Rzeszów 2014, s. 10. 
nej (asystent rodziny, wychowawcy świetlic specjalistycznych), kuratelę (kurator sądowy, kurator społeczny), ośrodki adopcyjno-opiekuńcze, poradnie psychologiczno-pedagogiczne, szkoły, fundacje, organizacje kościelne i inne powinni starać się podejmować wspólnie skoordynowane działania ${ }^{20}$. Specjaliści z zakresu różnych dziedzin, niosący pomoc dziecku i rodzinie, powinni przede wszystkim otrzymywać odpowiednie instrumenty do realizacji podejmowanej przez siebie pracy. Zasadne wydaje się tworzenie sieci wsparcia - szczególnie dla pracowników pomocy społecznej pracujących z dzieckiem i rodziną. Autorzy zwracają uwagę na potrzebę omawiania zagadnień związanych z relacjami: „pomoc społeczna - wymiar sprawiedliwości, rodziny zastępcze - sądy rodzinne, wspieranie rodzin wychowanków i rodzin zastępczych w środowisku lokalnym i wiele innych"21.

Można stwierdzić, że istnieje konieczność wskazywania takich kierunków usprawnień, które mogłyby służyć - szeroko rozumianej - rodzinie oraz pracownikom instytucji pomocowych reprezentującym różne dziedziny, aby charakter wykonywanej pracy rzeczywiście miał znamiona podejścia interdyscyplinarnego i dążył do zaprowadzania oczekiwanych zmian. Do pozytywnych aspektów podejmowania tak widzianej współpracy zalicza się dzielenie się wiedzą i zdobytym doświadczeniem, zwiększenie skuteczności udzielanej pomocy dzięki integracji podejmowanych działań, ogólny dostęp do wypracowanych i obowiązujących standardów, jakość sprawniejszego realizowania określonych zadań. Na wymienione korzyści oddziałują różne czynniki, jak np. wypracowanie wspólnych celów, niezakłócony przepływ konkretnych informacji, kompetencja czy dyspozycyjność osób ${ }^{22}$.

Podkreśla się też skuteczność wsparcia społecznego oraz jego znaczenie dla zapobiegania powstawaniu sytuacji wiążących się z koniecznością udzielania profesjonalnej pomocy dziecku i rodzinie. Za działania wspierające uważa się w tym miejscu różnego rodzaju dobra materialne, świadczenie wybranych usług (doradztwo) czy inicjowanie oraz intensyfikowanie wzajemnej współpra$\mathrm{cy}^{23}$. Mowa również o „współodczuwaniu na płaszczyźnie rozumienia empatycznego, formach uspołeczniania i dowartościowywania (wzmacnianie cech pozytywnych)"24. Takie postępowanie profilaktyczne ma bazować na wspomnianych

20 Por. M. Ruszkowska, Rodzina zastępcza jako podmiot działań socjalnych, [w:] Praca socjalna $z$ dziećmi..., dz. cyt., s. 148-149.

21 Por. M. Andrzejewski, Rozważania o tożsamości..., dz. cyt., s. 192.

22 Por. M. Makarinska i in., Współpraca instytucji..., dz. cyt., s. 9.

23 Por. M. Winiarski, Opieka, pomoc..., dz. cyt., s. 39.

24 Tamże. 
wcześniej mocnych stronach - wewnętrznych siłach rodziny rozumianej jako całość oraz jej poszczególnych członków ${ }^{25}$.

W końcu, „każda społeczność rodzinna jest «miejscem» tworzenia, gromadzenia, przetwarzania i gwarantowania osobie ludzkiej wielorakich wartości”26. Rodzinne przekazy stają się dla człowieka kompasem, drogowskazem bazującym na wyniesionych doświadczeniach, wartościach, przeżyciach i atmosferze rodzinnej, który ma określać, co jest w danym momencie właściwe, a co niepożądane ${ }^{27}$. Środowisko rodzinne ma szczególne znaczenie dla rozwoju osobowego - „rodzina z psychologicznego i pedagogicznego punktu widzenia jest wspólnotą, która oddziałuje najwcześniej, najdłużej, systematycznie i najintensywniej w najbardziej plastycznym okresie życia"28 człowieka.

\section{Wnioski końcowe}

Widać, jak bardzo ważne jest przygotowanie do wychodzenia naprzeciw wymaganiom, jakie stawia rodzinie otaczająca rzeczywistość, najbliższe otoczenie. Podejmowanie skutecznych działań jest możliwe w sytuacji, gdy dziecko i rodzina mają okazję otrzymać właściwe wsparcie ze strony instytucji pomocowych. W ten sposób mądrze pokierowana rodzina jest w stanie samodzielnie wypełniać swoje funkcje i realizować poszczególne zadania. Trzeba pamiętać, że rodziny zmagające się z trudnościami niejednokrotnie wątpią w możliwość zaprowadzenia niezbędnych zmian w swoim życiu. Bywają też nieufne wobec oferowanej im pomocy. Stąd zatem potrzeba, by „osoby pracujące z rodzinami posiadały profesjonalną wiedzę i przygotowanie, którą będą umiały zastosować”29. W niesieniu pomocy istotne są też pewne cechy: „zaangażowanie, zainteresowanie rodziną, wiarygodność (otwarta i czytelna postawa), tolerancyjność, autentyczność”30.

Współcześnie dostrzega się konieczność podejmowania szerokiej dyskusji na temat umiejętnego tworzenia warunków do rozwoju wszystkich członków rodziny. Nie bez znaczenia jest również niezbędna liczba wykształconych i do-

\footnotetext{
25 Por. tamże.

26 H. Skorowski, Prawa rodziny w społeczeństwie demokratycznym, [w:] Dokąd zmierzasz, współczesna rodzino?, red. M. Duda, A. Świerczek, Kraków 2013, s. 198.

27 Por. tamże.

28 A. Błasiak, Obszary, możliwości i potrzeby pedagogicznego wspomagania rodziny $w$ dzisiejszej rzeczywistości, [w:] Dokąd zmierzasz..., dz. cyt., s. 318.

29 A. Iłendo-Milewska, A. Wojtach, Psychopedagogiczne determinanty profesjonalnej pomocy rodzinie, [w:] W trosce o..., dz. cyt., s. 342.

30 Tamże.
} 
świadczonych specjalistów z zakresu niesienia pomocy dziecku i rodzinie, odpowiednio skonstruowane narzędzia do pracy oraz wiedza dotycząca jak najlepszego ich wykorzystania. Wszystko to wiąże się z nieustanną wymianą wypracowanych standardów podejmowanej pracy oraz zdobytych doświadczeń w niesieniu pomocy, wspieraniu dziecka i rodziny na drodze rozwoju. Współwystępowanie tych elementów mogłoby stanowić rzeczywistą szansę na realizację praktycznego wymiaru niesienia interdyscyplinarnej pomocy dziecku i rodzinie. Na zakończenie warto przytoczyć słowa cytowanego już Jana Pawła II, które odzwierciedlają tytułową troskę o rodzinę: „jeśli w przyjściu na świat oraz we wchodzeniu w świat człowiekowi brakuje rodziny, to jest to zawsze wyłom i brak nad wyraz niepokojący i bolesny, który potem ciąży nad całym życiem" ${ }^{31}$. Dlatego kierując się w podejmowanych działaniach dobrem dziecka i rodziny, trzeba przede wszystkim podążać za myślą, iż rodzina „jest drogą powszechną, pozostając za każdym razem drogą szczególną, jedyną i niepowtarzalną, tak jak niepowtarzalny jest każdy człowiek"32.

\section{Bibliografia}

Andrzejewski M., Rozważania o tożsamości zastępczego rodzicielstwa (i kilku drobniejszych sprawach), [w:] Pomoc społeczna wobec rodzin. Interdyscyplinarne rozważania o publicznej trosce o dziecko i rodzine, red. D. Trawkowska, Toruń 2011.

Błasiak A., Obszary, możliwości i potrzeby pedagogicznego wspomagania rodziny w dzisiejszej rzeczywistości, [w:] Dokąd zmierzasz, współczesna rodzino?, red. M. Duda, A. Świerczek, Kraków 2013.

Iłendo-Milewska A., Wojtach A., Psychopedagogiczne determinanty profesjonalnej pomocy rodzinie, [w:] W trosce o wspótczesna rodzinę. Teoria, badania, wsparcie. Ujęcie interdyscyplinarne.

Izdebska J., Rodzina wspótczesna, jej sytuacja życiowa potrzeba wsparcia, [w:] W trosce o wspótczesna rodzinę. Teoria, badania, wsparcie. Ujęcie interdyscyplinarne, red. J. Izdebska, A. Popławska, Białystok 2013.

Jan Paweł II, Adhortacja apostolska „Familiaris consortio” (22.11.1981).

Jan Paweł II, List do rodzin (2.02.1994).

Kalus A., Rodzina zastępcza, [w:] Psychologia rodziny, red. I. Janicka, H. Liberska, Warszawa 2014.

Kawczyńska-Butrym Z., Rodziny zależne od pomocy - wsparcie z zewnątrz - wykorzystanie zasady domina i synergii (DiS) oraz zasobów rodziny, [w:] Pomoc społeczna wobec rodzin.

31 Jan Paweł II, List do rodzin (2.02.1994), nr 2.

32 Tamże. 
Interdyscyplinarne rozważania o publicznej trosce o dziecko i rodzinę, red. D. Trawkowska, Toruń 2011.

Kotlarska-Michalska A., Dysfunkcje rodziny jako efekt przemian makrostrukturalnych, [w:] Pomoc społeczna wobec rodzin. Interdyscyplinarne rozważania o publicznej trosce o dziecko i rodzinę, red. D. Trawkowska, Toruń 2011.

Krasiejko I., Metodyka działania asystenta rodziny. Różne modele pracy socjalnej i terapeutycznej z rodzina, Katowice $2012^{2}$.

Makarinska M. i in., Wspótpraca instytucji pomocy społecznej z innymi instytucjami na terenie gminy, powiatu, województwa zajmującymi się pomoca i wsparciem rodzin i jej wplyw na skuteczność działań pomocy społecznej, red. M. Zajdel-Ostrowska i in., Rzeszów 2014.

Meissner-Łozińska J., Instytucje i organizacje wspierające dziecko i rodzine, [w:] Pomoc, opieka, wsparcie dziecka i rodziny, red. U. Gruca-Miąsik, Rzeszów 2006.

Opieka nad dzieckiem pozbawionym opieki rodzicielskiej, http://stat.gov.pl/obszary-tematyczne/ warunki-zycia/ubostwo-opieka-spoleczna/opieka-nad-dzieckiem-pozbawionym-opiekirodzicielskiej,5,2.html (12.06.2015).

Ruszkowska M., Diagnoza rodzin zastępczych w obliczu dylematów współczesności, Warszawa 2013.

Ruszkowska M., Rodzina zastępcza jako podmiot działań socjalnych, [w:] Praca socjalna z dziećmi, młodzieżą i rodzina, red. M. Ruszkowska, M. Winiarski, Warszawa 2014.

Skorowski H., Prawa rodziny w społeczeństwie demokratycznym, [w:] Dokąd zmierzasz, wspótczesna rodzino?, red. M. Duda, A. Świerczek, Kraków 2013.

Ustawa z dnia 9 czerwca 2011 roku o wspieraniu rodziny i systemie pieczy zastępczej (Dz. U. z dnia 21 lipca 2011 r. Nr 149, poz. 887).

Walęcka-Matyja K., Role i funkcje rodziny, [w:] Psychologia rodziny, red. I. Janicka, H. Liberska, Warszawa 2014.

Winiarski M., Opieka, pomoc i wsparcie jako wymiary pracy socjalnej z dziećmi, młodzie$\dot{z}$ a i rodzina, [w:] Praca socjalna z dziećmi, młodzieżą i rodzina, red. M. Ruszkowska, M. Winiarski, Warszawa 2014. 